\title{
NECTAR AND POLLEN PRODUCTION AND INSECT VISITATION ON ORNAMENTALS FROM THE GENUS HOSTA Tratt. (ASPARAGACEAE)
}

\author{
Małgorzata Bożek \\ Monika Strzałkowska-Abramek \\ Bożena Denisow* \\ Department of Botany, University of Life Sciences in Lublin \\ 15 Akademicka Street, 20-950 Lublin, Poland \\ *corresponding author: bozena.denisow@up.lublin.pl \\ Received 04 May 2015; accepted 11 August 2015
}

\begin{abstract}
Properly arranged ornamental gardens in both urban and agricultural landscapes can be of a benefit to bees. In this study, we observed the flowering phenology, nectar, and pollen production of the ornamental Hosta species and varieties $(H$. sieboldiana Engler, H. capitata Nakai, H. crispula Maekawa, $H$. fluctuans Maekawa, syn. $H$. sieboldiana var. fluctuans hort., $H$. undulata var. univittata Miquel (Hylander), syn. $H$. univittata). Our experiment was conducted in the 2012 - 2014 time period, at the UMCS Botanical Garden in Lublin, Poland $\left(51^{\circ} 14^{\prime} \mathrm{N}, 21^{\circ} 34^{\prime} \mathrm{E}\right)$. The total sugar yield varied almost 5 -fold among Hosta ornamentals; the lowest amount was calculated for $H$. fluctuans ( $2.31 \mathrm{~g}$ per $10 \mathrm{~m}^{2}$ ) and the highest for $H$. capitata $\left(11.80 \mathrm{~g}\right.$ per $\left.10 \mathrm{~m}^{2}\right)$. The average pollen yield was from $0.24 \mathrm{~g}$ per $10 \mathrm{~m}^{2}$ ( $H$. undulata var. univittata) to $9.53 \mathrm{~g}$ per $10 \mathrm{~m}^{2}$ (H. capitata). Pollen grains were bilaterally symmetrical, and large-sized. In polar view, they were prolatum (shape index $1.33-1.61$ ), while in equatorial view, oblatum (shape index $0.5-0.7$ ). Hosta species can complete the summer pasture mainly for bumblebees. In four of the five Hosta representatives, bumblebees accounted for $60-70 \%$ of the total visits. The honeybee predominated only on the flowers of $H$. capitata $(54-71 \%)$. Solitary bees were rarely observed ( $3-9 \%$ of visits). The phenotypic traits of Hosta flowers (the accumulation of nectar in the deep and narrow perianth tube) reduced the access to nectar reward and restricted an array of insect visitors.
\end{abstract}

Keywords: bee pasture, bumblebees, honeybees, Hosta, nectar, pollen.

\section{INTRODUCTION}

The forage base for pollinators is subjected to continuous changes and nutritional stress is considered an important factor that impact on the decline of pollinators (Alaux et al., 2010; GonzalezVaro et al., 2013). The promotion of flowering plants that attract pollinators by nectar and/or pollen has been well known to help to overcome the problem (Garbuzov et al., 2015). Improvement of bee pastures can support pollinators and may counteract the alarming reduction of their diversity and abundance. One of the ways to help pollinators is to cultivate ornamental garden plants (Kołtowski, 2006; Masierowska, 2006; Garbuzov et al., 2015). Properly arranged ornamentals can benefit bees in urban areas (Matteson et al., 2012) as well as enhance pollinators in the surrounding of intensively managed farmlands (Samnegård et al.,
2011). The favourable effect of the presence of ornamental gardens on pollination in adjacent crops has been recently documented (Рereira-Peixoto et al., 2014). However, the usefulness of ornamentals for pollinator-friendly gardens differs considerably between species or even between cultivars (Denisow and Strzałkowska-Abramek, 2013). To maximize the efforts for the design of pollinator-friendly gardens we primarily require the knowledge of floral reward accessibility and the value of nectar and pollen provided by flowers. In addition, the flowering biology and ecology observations are necessary to help the gardener choose insect-friendly flowers. Non-native plants particularly need great attention to evaluate if they are appropriate for the pollinator groups present outside of their natural environment (Wróblewska and Stawiarz, 2012; Denisow and Strzałkowska-Abramek, 2013). 
In this study, we determined the floral reward value of the Hosta species and varieties. These are popular ornamentals which are propagated in the modern garden design due to their versatility and usefulness for different arrangements (Grabowska and Kubala, 2012). In particular, we examined (i) blooming biology, (ii) nectar secretion, (iii) pollen production, (iv) pollen grain size and shape (useful for identification of pollen grains in microscopic analysis of bee products), and (v) the spectrum of insect visitors.

\section{MATERIAL AND METHODS}

\section{Study site and study species}

Our experiment was conducted in the 2012 2014 time period, in the Botanical Garden of Maria Curie-Skłodowska University in Lublin, Poland $\left(51^{\circ} 11^{\prime} \mathrm{N}, 22^{\circ} 28^{\prime} \mathrm{E}\right)$. The plants singled out for the study were $H$. sieboldiana Engler, $H$. capitata Nakai, H. crispula Maekawa, H. fluctuans Maekawa, syn. $H$. sieboldiana var. fluctuans hort., $H$. undulata var. univittata Miquel (Hylander), syn. $H$. univittata. The experimental individuals were grown in the collection of ornamental plants by the pond, under the shade of surrounding trees.

The genus Hosta includes about 45 species native to northeast Asia (China, Korea, Japan), they are mostly grown in wetlands and moist meadows. Several species have been introduced to Europe and widely cultivated as shade-tolerant foliage plants (Grabowska and Kubala, 2012). The genus is currently placed in the family Asparagaceae (APG III). Hosta species are herbaceous perennials, very popular, and frequently used as border and ground cover plants, suitable for planting near water bodies (Marcinkowski, 2007; Grabowska and Kubala, 2012). The advantage is that they grow well in a polluted city environment. In Poland, hostas are commonly cultivated. Hosta sieboldiana develops huge round, heavy textured greenish-blue leaves and light blue flowers. Hosta capitata has ovate leaves and purple flowers. The leaves of $H$. crispula are dark green, broadly margined with creamy-white, and the flowers are pale lavender. The leaves of $H$. fluctuans possess particularly protruding veins, and the flowers are light lavender. Hosta undulata var. univittata develop ovate, strongly twisted, deep green leaves, striped creamy-white in the centre; the flowers are light purple (Marcinkowski, 2007). In the natural environment, hostas are known to attract insect visitors (Takahashi et al., 1994).

\section{Flowering}

The protocols described by Denisow (2009; 2011) were applied during flowering observations. The phenology of flowering was established by means of the onset and length of the blooming period. To determine the flower lifespan, the buds ( $n=6-10$ per year) were randomly chosen and marked on different individual plants ( $n=3$ - 4). The flower lifespan was defined as the period from bud opening until perianth closing (observed only in 2012 - 2013). The number of flowers per raceme $(n=24-30)$ and the number of inflorescences per individual ( $n=5$ - 7) was established. The data were converted to the number of flowers per $10 \mathrm{~m}^{2}$ of the surface and used to estimate the total nectar and pollen yield.

\section{Nectar secretion}

Nectar production was only measured in 2012 and 2013. Nectar secreted in single flowers was collected using the pipette method (Jabłoński, 2002). Prior to nectar collecting, flowers were covered by tulle isolators to exclude insect visitors. Nectar collection was conducted in 3 - 5 replications during the blooming period. In each replication, 4 - 6 samples were collected. A single sample contained nectar from 4 - 7 flowers collected form 3 - 4 different individual plants The total sugar concentration was measured with an Abbe refractometer. Nectar volume and sugar concentration were used to calculate the total sugar mass in each sample. Relevant calculations allowed us to determine the amount of sugars produced per 10 flowers (in $\mathrm{mg}$ ) and per $10 \mathrm{~m}^{2}$ (in g). We excluded data for $H$. undulata var. univittata (during the study course some isolators were destroyed, and the remaining samples seemed to be unrepresentative).

\section{Pollen production}

For the full-blooming phase, pollen production was determined using the ether-ethanol method described in detail by Denisow (2011). The anther dry mass and the mass of produced pollen was assessed. Anthers were dissected and placed in tarred vessels prepared for this purpose. Samples were collected every year in four replications ( $n=60$ anthers in each replication). The samples were inserted in the ELCON CL 65 dryer, at ca. $33^{\circ} \mathrm{C}$. The pollen from anthers was rinsed once with pure ether $(1-2 \mathrm{~mL})$ and then 2 - 3 times with $70 \%$ ethanol $(2-8 \mathrm{~mL})$. The mass of produced pollen was calculated for 10 flowers (in $\mathrm{mg}$ ), and per $10 \mathrm{~m}^{2}$ (in g). 
Pollen grain dimensions were determined in glycerolgelatine slides (Erdtman, 1954) in 2013 and 2014. The lengths of the polar axis $(P)$ and two equatorial axes with distinct lengths (longitudinal $=E_{1}$ and transversal $=E_{2}$ ) were determined $(n=4 \times 50$ per year). The shape coefficients $\left(P / E_{1}\right.$ and $\left.E_{1} / E_{2}\right)$ were defined. These observations were conducted using a Nikon Eclipse 200 light microscope.

\section{Insect activity}

Insects visits were recorded from 7:00 a.m. until 6:00 p.m. (GMT $+2.00 \mathrm{~h}$ ) in two (three) hours intervals on random plots ( $n=3 ; 1 \mathrm{~m}^{2}$ per species). These observations were conducted for three consecutive days, at the full-bloom phase of the species. During each census of observation (3 - $6 \mathrm{~min}$ ), the total number of visiting insects was recorded and the type of forage (nectar vs. pollen) noted.

\section{Weather conditions}

In 2012 and 2013, air temperatures in Lublin in the period of blooming of Hosta species were 2.9 and $0.8^{\circ} \mathrm{C}$ higher than the long-term average. Total precipitation was approx. $26 \%$ lower than normal in 2012 , while it was on the average level in 2013.

\section{Statystical analysis}

Data are presented as means with SD. The KruskalWallis $\mathrm{H}$-test was used to determine the species effect for the flower life span (non-normally distributed data). Parametric statistical ANOVA was applied for the number of flowers and nectar and pollen traits. A post hoc comparison of the means was tested by the HSD Tukey's test. The level of statistical significance for all analyses was at $P=0.05$. All analyses were performed using Statistica ver. 6.0 (StatSoft Poland, Kraków).

\section{RESULTS}

The blooming of the Hosta species and varieties took place from the last decade of June to the first week of August. Hosta sieboldiana was the first to bloom, and was followed by $H$. fluctuans, $H$. capitata, $H$. crispula, and by $H$. undulata var. univittata (Tab. 1). The blooming duration for particular species differed 7 - 14 days between the years of the study. Irrespective of the year, the shortest blooming was characteristic for Hosta crispula (only 16 - 20 days), the longest for $H$. capitata (25 - 36 days). In 2014, the flowering onset of every species/variety was accelerated (10 - 14 days) as compared to the flowering times recorded in the previous years.
The flowers of Hosta representatives are arranged in raceme inflorescences. Within an inflorescence, flowering progresses acropetally from the bottom to the top positioned ones, with little flowering overlap among flowers. The individual flowers are perfect, actinomorphic. Perianth form a narrow tube, $10-30 \mathrm{~mm}$ in length. Hosta flowers opened before 8:00 a.m. The life span of the single flower in the raceme did not differ significantly in individual taxa (Kruskal-Wallis test: $\mathrm{H}=12.11, \mathrm{P}=0.114$ ). The longevity of individual flowers ranged between 20-38 hours.

The number of flowers per inflorescence and the number of stems per unit area was speciesrelated $\left(F_{4,104}=4.21, P=0.043\right.$ and $F_{4,36}=2.21$, $P=0.013$, respectively). The lowest number of flowers in inflorescences was noted for $H$. undulata var. univittata and $H$. crispula, and the highest for $H$. sieboldiana (Tab. 1). The number of flowers per inflorescence was not affected by the year of observation in any of the studied taxa. Among taxons, disparities in the number of flowers produced per $10 \mathrm{~m}^{2}$ were 2 - 7 fold.

The Hosta flowers attracted insect visitors by primary attractants (nectar and pollen) and secondary attractants (shape - funnel-bell; colour - white, lavender, light violet; soft scent). The fused perianth form a long tube (15 - $20 \mathrm{~mm})$, which is narrow at the base. Nectar is accumulated and hidden in the narrow tube. The intermediate flower part is formed like a broad tube. The nectarsecreting tissue is located in three septal nectaries in the flowers of Hosta species and varieties. The nectar is exudated outside the pistil via outlets and is accumulated in the spaces between the ovary and the staminal filaments. The level of secreted nectar usually reaches to $1 / 4-1 / 2$ of the narrow tube. Nectar was secreted already in the bud. In the first hours of the life-span, the pollen is released from the anthers and is presented to the insect visitors, pollen exposition under sunny and dry weather lasts for about 5 - 7 hours per flower. The sugar concentration in nectar differed between studied Hosta representatives $\left(F_{3,54}=3.11, P=0.021\right)$. The sugar concentration in the nectar of $H$. fluctuans was almost 2-fold higher compared with that of H. crispula (Tab. 2). No species effect was found for the sugar-mass, produced in flowers $\left(F_{3,54}=21.5\right.$, $P=0.096)$. The sugar mass differed considerably between years in the flowers of $H$. sieboldiana $\left(F_{1,8}=2.11, P=0.047\right)$ and $H$. capitata $\left(F_{1,8}=3.16\right.$, $P=0.031)$. The average sugar yield per $10 \mathrm{~m}^{2}$ varied almost 2-5-fold among Hosta representatives (2.31 - $11.80 \mathrm{~g})$. 
Table 1.

Phenology of flowering and abundance of blooming for Hosta representatives studied in the 2012 - 2014 time period. Mean values \pm SD are given

\begin{tabular}{|c|c|c|c|c|c|c|c|c|c|}
\hline \multirow{2}{*}{ 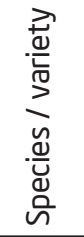 } & \multirow[t]{2}{*}{ Year } & \multicolumn{2}{|c|}{ Flowering } & \multicolumn{2}{|c|}{$\begin{array}{l}\text { Number of flowers } \\
\text { per inflorescence }\end{array}$} & \multicolumn{2}{|c|}{$\begin{array}{c}\text { Number } \\
\text { of inflorescences } \\
\text { per } 1 \mathrm{~m}^{2}\end{array}$} & \multicolumn{2}{|c|}{$\begin{array}{l}\text { Number } \\
\text { of flowers } \\
\text { per } 10 \mathrm{~m}^{2} \\
\text { thous. }\end{array}$} \\
\hline & & Date & Length (days) & Mean & \pm SD & Mean & $\pm S D$ & Mean & $\pm S D$ \\
\hline \multirow{4}{*}{$\Sigma \frac{\frac{.0}{\frac{\pi}{0}}}{\frac{0}{\frac{d}{n}}}$} & 2012 & 3.07 - 25.07 & 23 & 30.9 & 4.8 & $7.1_{a}$ & 4.0 & 2.19 & 0.9 \\
\hline & 2013 & 7.07 - 26.07 & 20 & $37.4_{a}$ & 11.8 & $7.8_{a}$ & 2.8 & 2.92 & 1.1 \\
\hline & 2014 & $19.06-16.07$ & 28 & $41.2_{a}$ & 9.4 & $9.7_{b}$ & 2.1 & 4.00 & 1.5 \\
\hline & Mean & & 23.7 & $36.5_{c}$ & & $8.2_{A}$ & & 3.04 & \\
\hline \multirow{4}{*}{ 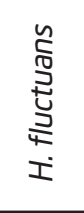 } & 2012 & $4.07-27.07$ & 24 & $24.8_{\mathrm{a}}$ & 3.9 & $6.2_{a}$ & 3.1 & 1.54 & 1.8 \\
\hline & 2013 & 9.07 - 28.07 & 20 & $30.0_{a}$ & 6.8 & $5.8_{\mathrm{a}}$ & 2.4 & 1.74 & 1.2 \\
\hline & 2014 & $23.06-21.07$ & 29 & $28.3_{a}$ & 5.3 & $6.8_{a}$ & 1.3 & 1.92 & 2.0 \\
\hline & Mean & & 24.3 & $27.7_{B}$ & & $6.3_{A}$ & & 1.73 & \\
\hline \multirow{4}{*}{$\Sigma \cdot \frac{\sqrt[0]{0}}{\frac{0}{0}}$} & 2012 & 7.07 - 3.08 & 28 & $26.4_{a}$ & 3.2 & $30.3_{a}$ & 1.5 & 8.00 & 4.2 \\
\hline & 2013 & $8.07-01.07$ & 25 & $30.6_{a}$ & 4.2 & $29.8_{a}$ & 3.2 & 9.12 & 3.1 \\
\hline & 2014 & $20.06-25.07$ & 36 & $29.5_{a}$ & 4.9 & $32.8_{a}$ & 5.4 & 9.68 & 5.5 \\
\hline & Mean & & 27.7 & $28.8_{B}$ & & $31.0_{c}$ & & 8.93 & \\
\hline \multirow{4}{*}{ 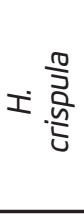 } & 2012 & 8.07 - 26.07 & 19 & $22.1_{a}$ & 8.2 & $11.2_{a}$ & 2.4 & 2.48 & 1.1 \\
\hline & 2013 & $12.07-27.07$ & 16 & $27.2_{a}$ & 10.6 & $14.3_{\mathrm{ab}}$ & 1.3 & 3.89 & 0.8 \\
\hline & 2014 & $28.06-17.07$ & 20 & $25.7_{a}$ & 8.0 & $15.8_{b}$ & 3.7 & 4.06 & 2.1 \\
\hline & Mean & & 18.3 & $25.0_{A B}$ & & $13.8_{B}$ & & 3.48 & \\
\hline \multirow{4}{*}{ 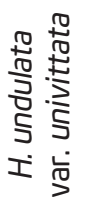 } & 2012 & 10.07 - 29.07 & 20 & $16.6_{a}$ & 3.2 & $13.2_{a}$ & 4.5 & 2.19 & 2.3 \\
\hline & 2013 & 14.07 - 30.07 & 17 & $19.0_{a}$ & 2.7 & $10.9_{a}$ & 3.2 & 2.07 & 1.7 \\
\hline & 2014 & $26.06-21.07$ & 26 & $18.2_{a}$ & 2.5 & $11.2_{a}$ & 2.6 & 2.04 & 2.0 \\
\hline & Mean & & 21.0 & $17.9_{A}$ & & $11.8_{B}$ & & 2.10 & \\
\hline
\end{tabular}

Means within columns with the same small letter do not differ significantly between years within a species, and the means with the same capital letter do not differ significantly between species at $\mathrm{P}<0.05$, based on HSD Tukey's test.

Table 2.

Concentration of nectar and amount of sugars produced by Hosta representatives during the two study years. The mean values \pm SD are given

\begin{tabular}{|c|c|c|c|c|c|c|c|c|}
\hline \multirow{3}{*}{ Species } & \multirow{3}{*}{ Yеar } & \multirow{3}{*}{$\begin{array}{c}\text { Number of } \\
\text { examined } \\
\text { flowers }\end{array}$} & \multirow{2}{*}{\multicolumn{2}{|c|}{$\begin{array}{c}\text { Concentration of sugars } \\
\text { in nectar (\%) }\end{array}$}} & \multicolumn{4}{|c|}{ Total sugars yield } \\
\hline & & & & & \multicolumn{2}{|c|}{ per 10 flowers $(\mathrm{mg})$} & \multicolumn{2}{|c|}{$\mathrm{g} / \mathrm{m}^{2}$} \\
\hline & & & Mean & $\pm \mathrm{SD}$ & Mean & \pm SD & Mean & $\pm S D$ \\
\hline \multirow{3}{*}{$\begin{array}{c}H . \\
\text { sieboldiana }\end{array}$} & 2012 & 125 & $18.5_{a}$ & 5.5 & 9.4 & 3.2 & 2.06 & 0.7 \\
\hline & 2013 & 103 & $23.6_{a}$ & 2.4 & $17.1_{\mathrm{b}}$ & 2.5 & 4.99 & 1.3 \\
\hline & Mean & & $21.05_{A B}$ & & $13.2_{A}$ & & 3.53 & \\
\hline \multirow{3}{*}{ H. fluctuans } & 2012 & 110 & $32.4_{a}$ & 6.3 & $13.8_{a}$ & 4.3 & 2.12 & 1.4 \\
\hline & 2013 & 120 & $37.2_{a}$ & 4.8 & $14.3_{\mathrm{a}}$ & 2.6 & 2.49 & 1.6 \\
\hline & Mean & & $34.80_{B}$ & & $14.0_{A}$ & & 2.31 & \\
\hline \multirow{3}{*}{$\begin{array}{c}\text { H. } \\
\text { capitata }\end{array}$} & 2012 & 121 & $18.5_{a}$ & 8.5 & $9.2_{a}$ & 3.8 & 7.36 & 2.8 \\
\hline & 2013 & 108 & $26.6_{b}$ & 6.9 & $17.8_{b}$ & 5.2 & 16.23 & 6.2 \\
\hline & Mean & & $19.85_{A}$ & & $13.5_{A}$ & & 11.80 & \\
\hline \multirow{3}{*}{$\begin{array}{c}H . \\
\text { crispula }\end{array}$} & 2012 & 115 & $15.3_{\text {a }}$ & 7.1 & $16.6_{a}$ & 5.4 & 4.11 & 0.5 \\
\hline & 2013 & 135 & $20.5_{b}$ & 5.8 & $15.3_{a}$ & 3.9 & 5.95 & 2.7 \\
\hline & Mean & & $17.90_{\mathrm{A}}$ & & $15.9_{A}$ & & 5.03 & \\
\hline
\end{tabular}

ANOVAs procedures were performed separately for each analysed feature. Means with the same small letter do not differ significantly between years within a species, and the means with the same capital letter do not differ significantly between species, at P<0.05, based on HSD Tukey's test. 
Table 3.

Pollen production and pollen viability of Hosta representatives in the 2012 - 2014 time period. The mean values \pm SD are given

\begin{tabular}{|c|c|c|c|c|c|c|}
\hline \multirow{3}{*}{ Species / variety } & \multirow{3}{*}{ Year } & \multicolumn{5}{|c|}{ Pollen production } \\
\hline & & \multicolumn{3}{|c|}{ per 10 flowers $(\mathrm{mg})$} & \multicolumn{2}{|c|}{$\mathrm{g} / \mathrm{m}^{2}$} \\
\hline & & Min - max & Mean & $\pm \mathrm{SD}$ & Mean & $\pm \mathrm{SD}$ \\
\hline \multirow{4}{*}{ H. sieboldiana } & 2012 & $1.1-5.7$ & $3.6_{a}$ & 3.2 & 0.79 & 0.6 \\
\hline & 2013 & $1.5-4.1$ & $2.9_{a}$ & 2.6 & 0.85 & 0.5 \\
\hline & 2014 & $1.2-5.0$ & $3.6_{a}$ & 1.4 & 1.44 & 0.7 \\
\hline & Mean & & $3.4_{B}$ & & 1.02 & \\
\hline \multirow{4}{*}{ H. fluctuans } & 2012 & $0.6-5.9$ & $3.9_{a}$ & 2.6 & 0.60 & 0.2 \\
\hline & 2013 & $1.7-5.0$ & $3.6_{a}$ & 1.0 & 0.63 & 0.3 \\
\hline & 2014 & $1.2-6.0$ & $4.4_{a}$ & 1.8 & 0.85 & 0.5 \\
\hline & Mean & & $4.0_{B}$ & & 0.69 & \\
\hline \multirow{4}{*}{ H. capitata } & 2012 & $4.2-18.1$ & $9.7_{a}$ & 3.5 & 7.76 & 1.9 \\
\hline & 2013 & $3.5-14.7$ & $11.7_{\mathrm{a}}$ & 5.7 & 10.67 & 4.3 \\
\hline & 2014 & $4.3-17.0$ & $10.5_{a}$ & 4.5 & 10.16 & 4.9 \\
\hline & Mean & & $10.6_{D}$ & & 9.53 & \\
\hline \multirow{4}{*}{ H. crispula } & 2012 & $1.9-8.5$ & $6.2_{a}$ & 4.8 & 1.53 & 3.6 \\
\hline & 2013 & $1.3-6.9$ & $7.5_{b}$ & 3.8 & 2.92 & 4.6 \\
\hline & 2014 & $2.2-9.4$ & $5.9_{a}$ & 2.3 & 2.40 & 5.3 \\
\hline & Mean & & $6.5_{c}$ & & 2.28 & \\
\hline \multirow{4}{*}{$\begin{array}{l}\text { H. undulata } \\
\text { var. univittata }\end{array}$} & 2012 & $0.3-1.6$ & $0.8_{a}$ & 0.5 & 0.18 & 0.2 \\
\hline & 2013 & $0.8-2.0$ & $1.6_{b}$ & 1.0 & 0.33 & 0.1 \\
\hline & 2014 & $0.2-1.6$ & $1.1_{b}$ & 0.5 & 0.22 & 0.1 \\
\hline & Mean & & $1.2_{\mathrm{A}}$ & & 0.24 & \\
\hline
\end{tabular}

ANOVAs procedures were performed separately for each analysed feature. The means with the same small letter do not differ significantly between years within a species and the means with the same capital letter do not differ significantly among species, at $P<0.05$. based on HSD Tukey's test.

Table 4

Morphological characters of pollen grains of five Hosta species (the mean for 2013 - 2014)

\begin{tabular}{|c|c|c|c|c|c|c|c|c|}
\hline \multirow{3}{*}{ Species } & \multicolumn{6}{|c|}{ Length of axis $(\mu \mathrm{m})$} & \multirow{2}{*}{\multicolumn{2}{|c|}{ Shape index }} \\
\hline & \multicolumn{2}{|c|}{ Polar (P) } & \multicolumn{2}{|l|}{$\left(E^{1}\right)$} & \multicolumn{2}{|c|}{ Equatorial transverse } & & \\
\hline & $\left(E^{2}\right)$ & $\begin{array}{l}\text { Mean } \\
( \pm \text { SD })\end{array}$ & Min - max & $\begin{array}{l}\text { Mean } \\
( \pm S D)\end{array}$ & Min - max & $\begin{array}{r}\text { Mean } \\
( \pm \text { SD) }\end{array}$ & $P / E^{1}$ & $E^{1} / E^{2}$ \\
\hline H. sieboldiana & $43.4-59.9$ & $\begin{array}{l}52.4 \\
(6.7) \\
\end{array}$ & $78.4-107.6$ & $\begin{array}{l}95.4 \\
(8.6) \\
\end{array}$ & $44.2-71.6$ & $\begin{array}{c}59.2 \\
(10.0)\end{array}$ & 0.5 & 1.6 \\
\hline H. fluctuans & $32.5-58.8$ & $\begin{array}{c}44.4 \\
(10.6)\end{array}$ & $66.2-88.1$ & $\begin{array}{l}80.0 \\
(7.6)\end{array}$ & $43.5-68.2$ & $\begin{array}{l}53.7 \\
(8.7)\end{array}$ & 0.6 & 1.5 \\
\hline H. capitata & $30.7-51.6$ & $\begin{array}{l}41.2 \\
(6.6)\end{array}$ & $65.9-93.7$ & $\begin{array}{l}81.9 \\
(8.0)\end{array}$ & $38.3-81.7$ & $\begin{array}{c}51.4 \\
(10.9)\end{array}$ & 0.5 & 1.6 \\
\hline H. crispula & $44.6-67.1$ & $\begin{array}{l}53.9 \\
(8.4)\end{array}$ & $64.4-90.7$ & $\begin{array}{l}82.1 \\
(8.3)\end{array}$ & $47.4-69.3$ & $\begin{array}{l}61.7 \\
(6.5)\end{array}$ & 0.7 & 1.3 \\
\hline $\begin{array}{l}\text { H. undulata var. } \\
\text { univittata }\end{array}$ & $44.9-50.6$ & $\begin{array}{l}48.7 \\
(2.5)\end{array}$ & $66.5-103.4$ & $\begin{array}{l}85.8 \\
(9.0) \\
\end{array}$ & $43.4-66.6$ & $\begin{array}{l}56.1 \\
(6.5)\end{array}$ & 0.6 & 1.5 \\
\hline
\end{tabular}

E - equatorial longitudinal axis 


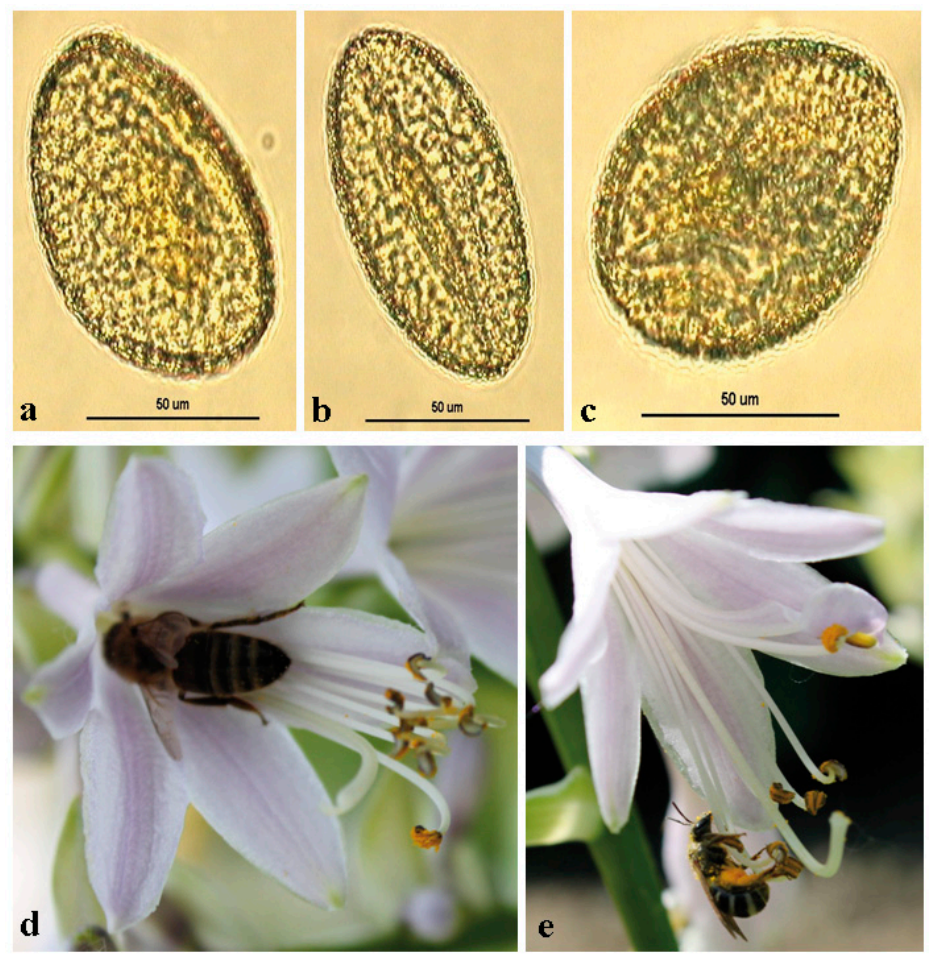

Fig. 1. Light micrographs of the pollen grains of Hosta capitata in a. equatorial view b. distal polar view and c. proximal polar view; insect visitors d. Apis mellifera, e. Halictus sp.

The flowers of the Hosta species contained 6 stamens that extended over six lobes of the perianth and curved inward. The anther size differed between species $\left(F_{4,58}=7.6, P=0.022\right)$ and consequently, the mass of the pollen produced in flowers $\left(F_{4,58}=4.8\right.$, $P=0.012)$. The amount of pollen produced was the highest in the flowers of $\mathrm{H}$. capitata, and the lowest in $H$. undulata var. univittata (Tab. 3 ). The average pollen yield per $10 \mathrm{~m}^{2}$ was from $0.24 \mathrm{~g}(\mathrm{H}$. undulata var. univittata) to $9.53 \mathrm{~g}$ ( $H$. capitata).

Pollen grains of the Hosta species were bilaterally symmetrical (Fig. 1a - c). The length of the polar axis (P) ranged from $30.7 \mu \mathrm{m}$ to $67.1 \mu \mathrm{m}$ (Tab. 4). The longitudinal equatorial axis $\left(E_{1}\right)$ was the longest for $H$. sieboldiana (mean $=95.4 \mu \mathrm{m}$ ), the shortest for $H$. fluctuans (mean $=80.0 \mu \mathrm{m}$ ). In polar view, the $E_{1} / E_{2}$ ratio ranged between 1.33 - 1.61. In equatorial view, the ratio of the polar to equatorial longitudinal axis $\left(P / E_{1}\right)$ ranged between 0.5 and 0.7 .

On average, the most frequent insect visitors recorded on the flowers of $H$. sieboldiana, $H$. fluctuans, $H$. crispula, and $H$. undulata var. univittata were bumblebees, responsible for $60-70 \%$ of total insect visits (Fig. 2). We observed only B. terrestris (L.), B. lapidarius (L.), B. pascuorum (Scopoli), and Bombus hortorum (L.). Regardless of the study year, the honeybee predominated on the flowers of $H$. capitata, comprising $54-71 \%$ of the visits (Fig. 1d). Solitary bees were rare visitors (3 - 9\%) and were almost exclusively interested in pollen (Fig. 1e). The activity of bumblebees on Hosta flowers started in the early morning hours about 7:00 a.m. and was relatively constant throughout the entire day until 6:00 p.m. Most honey bees and solitary bees were observed on the flowers between 10:00 a.m. and 3:00 p.m. Honeybees collected both nectar and pollen, with nectar being the more attractive goal.

\section{DISCUSSION}

The value of the nectar and pollen of the Hosta species for insect visitors was not empirically evaluated, therefore our results have no equivalent in the literature data. If arranged together in ornamental gardens, the species will provide nectar and pollen from the second decade of June ( $H$. sieboldiana) until the first week of August (H. capitata). The blooming period of the Hosta species established in our study, is similar to that stated for Poland by Marcinkowski (2007). It is worth noting, that the flowering phenology of particular ornamentals studied did not differ considerably among the growing seasons, indicating that the studied hostas are not sensitive to abiotic factors, e.g. cyclic changes in weather as regards 

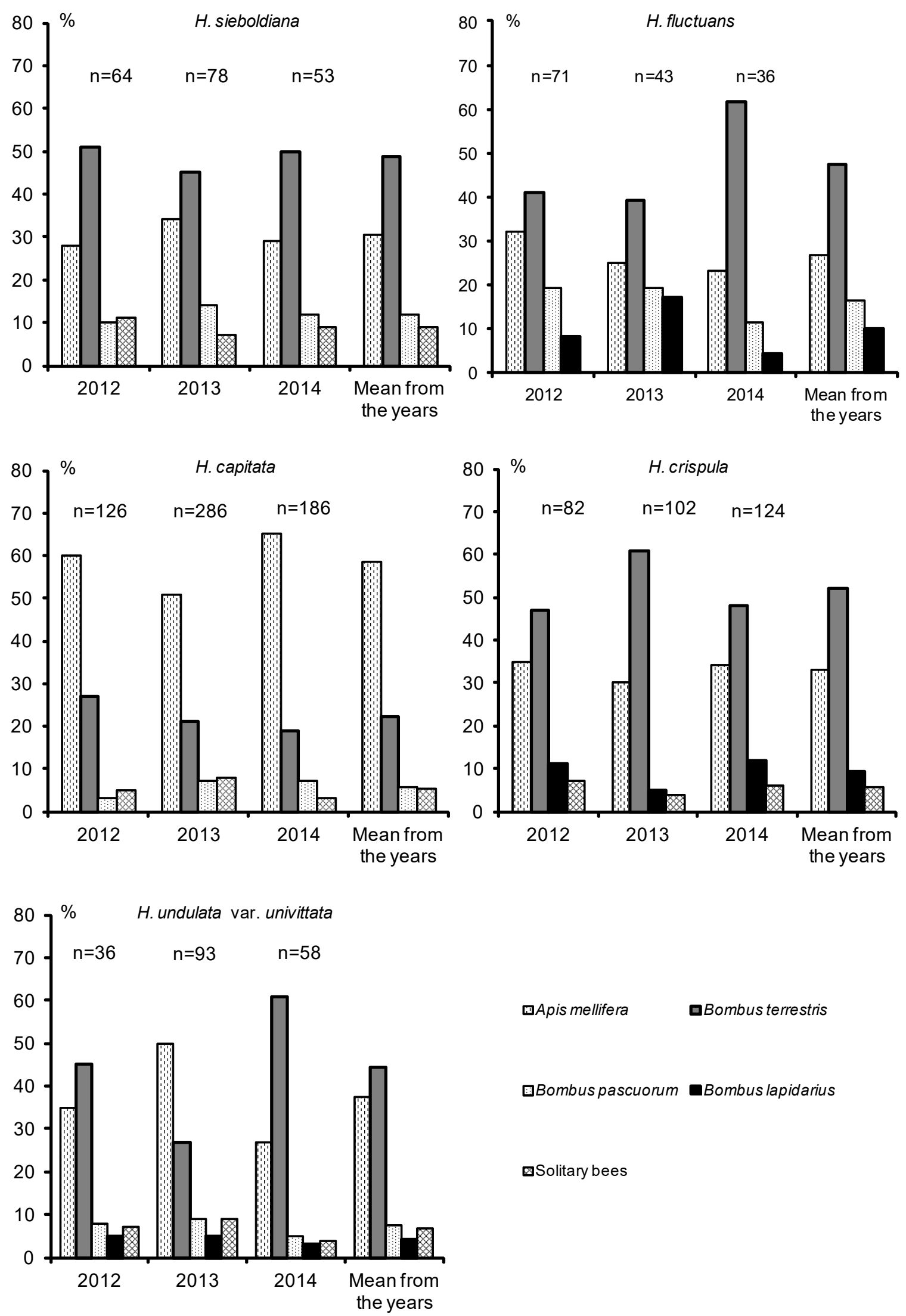

$\triangle$ Solitary bees

Fig. 2. The percentage participation of insect visitors on flowers of Hosta representatives. Mean values for the years of study are given; $n=$ the total number of insect visitors recorded. 
the conditions noted over the years of the study. Consequently, there is a high degree of probability of year-to-year repeatable food resources for insects, during a period when the assortment of blooming ornamentals for pollinator-friendly gardens is markedly declining in Poland (Kołtowski, 2006).

Our observations concerning the inter-species differences in the number of flowers per inflorescence are in accordance with descriptions of Marcinkowski (2007), and Grabowska and Kubala (2012), and indicate that the trait is highly genetically determined. Interestingly, the number of flowers per inflorescence did not differ substantially among growing seasons for any of the species studied. These results may suggest a high resistance of bud formation to exogenous conditions (e.g. air temperature, water balance). This is a unique feature. In a great number of species, the flower-bud set has been described as sensitive to weather factors (Chmiel, 2010). In perennial species, the onset of flowering is highly dependent on the resources accumulated in the stored organs as well as of resource allocation and/or current foliar photosynthetic efficiency during bud formation (Cao et al., 2007).

Open perianth of the studied Hosta species lasted only 20 - 36 hours, which is consistent with the findings of Cao et al. (2007) for $H$. rectifolia (only 1 day of flower life span) and with the observation of Chwil (2009) for $H$. fortunei (approx. 2 days of flower life span). The flower life span is speciesspecific (van Doorn, 1997; Masierowska, 2006; Denisow et al., 2014b), but is also under the control of various exogenous factors, e.g. the air temperature, air humidity, and whether or not the flower is pollinated (Ashman and Shoen, 1994; Denisow, 2009). Generally, flower life span has an ecological, genetic, and physiological significance (Waser et al., 1996). It impacts on the number of open flowers per inflorescence (= display size) and influences the rate of availability of floral reward for flower visitors (van Doorn, 1997). On a given day, only one or two Hosta flowers per inflorescence are in anthesis and expose nectar and pollen available for flower visitors. Accordingly, the limited quantity of the reward offered at a given time may partly explain the low frequency of insect visitors to hostas flowers.

In the genus Hosta, flowers tend to secrete a low to medium concentrated nectar. Chwil (2009) measured 23 - 30\% sugar concentration in the nectar of $H$. fortunei. Sugar concentration could be related to nectary characteristics and the type of sucrose transport across the nectary tissue (Nicolson and Thornburg, 2007). It is also related to changeable weather parameters (Denisow et al., 2014a). Variations in meteorological conditions (air humidity, air temperature) may explain the year-toyear differences in the nectar sugar concentration noted in two out of three Hosta species studied.

Bumblebees predominated on the flowers of five out of six Hosta representatives studied. Different Bombus species were described as the most frequent visitors to $H$. sieboldiana by Suzuki et. al. (2003), who consider them the true pollinators. It is unclear why insects favour certain flowers. Our observations suggest that flower morphology rather than nectar characteristics restrict insect visitors to the flowers of Hosta species. It is accepted that nectar traits have an impact on the spectrum of insect visitors (Galetto and Bernardello, 2004). According to different authors, the optimal range of nectar concentration for bumblebee forage is $50-65 \%$, and for honeybee forage is $25-40 \%$ (Nicolson and Thornburg, 2007). In our study, nectar 'suitable for honeybees' was avoided by honeybee foragers, whereas nectar of a lower concentration than 'optimal for bumblebees' was willingly collected by bumblebees. In general, a majority of studies have documented that the behaviour of foragers is complex. The broad space at the intermediate part of funnel-bell shaped Hosta flowers allows both honeybees and bumblebees to enter the perianth when nectar probing. On the other hand, the gradually narrowing perianth between the narrowand broad-tube parts of the flower might enable insect species with a short proboscis to enter the narrow tube and to reach the nectar hidden deeply inside. Presumably, due to floral morphology, the foraging behaviour of bumblebees and honeybees differed. The vast majority of bumblebees, after one visit to the Hosta flower, continued nectarfeeding at subsequent flowers. But most honeybee individuals, after one floral visit, escaped from the flowers and did not continue to forage for nectar in other flowers. The only exception was $H$. capitata, whose flowers were predominantly foraged by honeybees. The interest of honeybees in the flowers of $H$. capitata was presumably attributable to the relatively high amount of sugars produced per unit area (2 - 5 fold more compared to other hostas). The energy intake rate is considered an important factor in honeybee diet selection (Fewell and Winston, 1996; Osborne et al., 2008). In general, the relationship between phenotypic floral traits and/ or floral-reward characteristics and insect-visitor 
frequency are common interdependences (Willmer and Stone, 2004). Year-to-year changes in visitor frequency observed in our study, is also a commonly reported phenomena and is usually directly related to fluctuations in the insect population size between growing seasons (Goulson, 1999).

There is more and more evidence that the limitation of floral resources is among the reasons for the pollinators' decline (Alaux et al., 2010). Therefore, the quantity of floral reward offered, is an important factor to consider during the selection of plants for bee-friendly gardens. Overall, the total sugar yield of the Hosta species studied was low, only 2.31 $11.80 \mathrm{~g}$ per $10 \mathrm{~m}^{2}$. Likewise, the pollen production amounted to $0.24-9.53 \mathrm{~g}$ per $10 \mathrm{~m}^{2}$. These values place the hostas among poor sugar and pollen yielding plants (Kołtowski, 2006).

Pollen grains of the Hosta species and varieties are large in size, as they are within the range of 50 $100 \mu \mathrm{m}$ (Erdtman, 1954). According to Liu et al. (2011), pollen grains of the Hosta species are longellipsoidal or ellipsoidal. In our study, the mean shape index (Erdtman, 1954) in polar view, classify the pollen grains as prolatum (shape index $1.33-1.61$ ), while in equatorial view as oblatum (shape index 0.5 - 0.7). The pollen shape of Hosta representatives indicates a similarity with that of related genera, i.e. Hemerocallis, Agave, Yucca (Chung and Jones, 1989).

\section{CONCLUSION}

Under the environmental conditions of SE Poland, the ornamental Hosta species flower continuously from the second decade of June until the first week of August. The phenotypic traits of the Hosta flowers, including a deep, narrow perianth tube, reduce the access to nectar reward and restrict an array of insect visitors. Although the total sugar mass and pollen production are low in the Hosta species, the flowers can complete the summer pasture, particularly for bumblebees which are the key visitors.

\section{ACKNOWLEDGEMENTS}

This research was supported financially by the Ministry of Science and Higher Education of Poland (project OKB/DS/2) as a part of statutory activities of the Department of Botany, the University of Life Sciences, in Lublin. We are grateful to two anonymous reviewers for their valuable comments on an earlier version of the manuscript. Our thanks also go to Dr. hab. Anna Wróblewska, Prof. UP and to Dr. Ernest Stawiarz for making the microphotographic documentation possible. We thank Jacek Jachuła and Paula Poleszak for assistance with the field observations.

\section{REFERENCES}

Alaux C., Ducloz F., Crauser D., Le Conte Y. (2010) Diet effects on honeybee immunocompetence. Biology Letters 6: 562-565. D0l: 10.1098/rsbl.2009.0986

Ashman T. L., Shoen D. J. (1994) How long should a flower live? Nature 371: 788-790.

Cao G. X., Kudo G., Ida T. Y. (2007) Floral sex allocation in a hermaphrodite herb with 1 -day flowers, Hosta rectifolia (Liliaceae). Plant Species Biology 22: 191-196. DOl: 10.1111/j.1442-1984.2007.00191.x

Chmiel H. (2010) Uprawa roślin ozdobnych. Państwowe Wydawnictwo Rolnicze i Leśne. Warszawa. 900 pp.

Chung M. G., Jones S. B. (1989) Pollen morphology of Hosta Tratt. (Funkiaceae) and related genera. Bulletin of the Torrey Botanical Club 1 16(1): 31-44.

Chwil M. (2009) The structure of secretory tissue of the stigma and septal nectaries as well as nectar secretion of flowers of Hosta fortuneiBaker L. H. Bailey (Funkiaceae). Acta Agrobotanica 62(1): 27-36.

Denisow B. (2009) Factors determining diurnal dynamics of blooming of chosen plants species. Acta Agrobotanica 62(1): 83-89. DOl: 10.5586/aa.2009.010

Denisow B. (201 1) Pollen production of selected ruderal plant species in the Lublin area. University of Life Sciences Press. Lublin. 86 pp.

Denisow B., Strzałkowska-Abramek M. (2013) Characteristics of blooming and pollen in flowers of two Syringa species (f. Oleaceae). Acta Agrobotanica 66(4): 65-72. DOl: 10.5586/aa.2013.052

Denisow B., Strzałkowska-Abramek M., Bożek M., Jeżak A. (2014a) Early spring nectar and pollen and insect visitor behavior in two Corydalis species (Papaveraceae). Journal of Apicultural Science 58(1): 93-102. D0l:10.2478/jas2014-0009 
Denisow B., Wrzesień M., Bożek M., Jeżak A., StrzałkowskaAbramek M. (2014b) Flowering, pollen characteristics and insect foraging on Campanula bononiensis (Campanulaceae), a protected species in Poland. Acta Agrobotanica 67(2): 13-22. DOI: 10.5586/aa.2014.021

Erdtman G. (1954) An introduction to pollen analysis. Chronica Botanica. Waltham. Mass. USA. 239 pp.

Fewell J. H., Winston M. L. (1996) Regulation of nectar collection in relation to honey storage levels by honey bees, Apis mellifera. Behavioral Ecology 7(3): 286-291.

Galetto L., Bernardello G. (2004) Floral nectaries, nectar production dynamics and chemical composition in six Ipomoea species (Convolvulaceae) in relation to pollinators. Annals of Botany 94: 269-280.

Garbuzov M., Madsen A., Francis L.W., Ratnieks F.L.W. (2015) Patch size has no effect on insect visitation rate per unit area in garden-scale flower patches. Acta Oecologica 62: 53-57. DOI: 10.1016/j.actao. 12.002

Gonzalez-Varo J. P, Biesmeijer J. C., Bommarco R., Potts S. G., Schweiger O., Smith H. G., Steffan-Dewenter I., Hajnalka Szentgyogyi H., Woyciechowski M., Montserrat Vila M. (2013) Combined effects of global change pressures on animal-mediated pollination Trends in Ecology \& Evolution. 28(9): 524-530. DOl: 10.1016/j. tree.2013.05.008

Goulson D. (1999) Foraging strategies of insects for gathering nectar and pollen, and implications for plant ecology and evolution. Perspectives in Plant Ecology, Evolution and Systematics 2: 185-209. DOl: 10.1078/1433-8319-00070

Grabowska B., Kubala T. (2012) Encyklopedia roślin. Zysk i S-ka Wydawnictwo. Poznań. 997 pp.

Jabłoński B. (2002) Notes on the method to investigate nectar secretion rate in flowers. Journal of Apicultural Science 46(2): 117-125.

Kołtowski Z. (2006) Wielki atlas roślin miododajnych. Przedsiębiorstwo Wydawnicze Rzeczpospolita. Warszawa. 327 pp.

Liu J.-X., Zhao C.-H., Liu X.-R., Xi Y.-Z., Zhang Y.-L. (2011) Pollen morphology of Hosta Tratt. in China and its taxonomic significance. Plant Systematics and Evolution 294: 99-107. DOI 10.1007/s0060601 1-0448-9
Marcinkowski J. (2007) Byliny ogrodowe. Państwowe Wydawnictwo Rolnicze i Leśne. Warszawa. 419 pp.

Masierowska M. (2006) Flowering and nectar and pollen flow in Geranium sanguineum L., Geraniaceae. Acta Agrobotanica 59 (1): 165-175. DOl: 10.5586/ a.2006.017

Matteson K. C., Grace J. B., Minor E. S. (2012) Direct and indirect effects of land use on floral resources and flowervisiting insects across an urban landscape. Oikos 122(5): 682-694. DOl: 10.1 111 /j.1600-0706.2012.20229.x

Nicolson S. W., Thornburg R. W. (2007) Nectar chemistry. In: Nicolson S. W., Nepi M., Pacini E. (Eds.) Nectaries and Nectar. Springer. Dordrecht: 215-264.

Osborne J. L., Martin A. P., Shortall Ch. R., Todd A. D., Goulson D., Knight M. E., Hale R. J., Sanderson R. A. (2008) Quantifying and comparing bumblebee nest densities in gardens and countryside habitats. Journal of Applied Ecology 45: 784-792. DOl: 10.1111/j.13652664.2007.01359.x

Pereira-Peixoto M. H., Pufal G., Martins C. F., Klein A. M. (2014) Spillover of trap-nesting bees and wasps in an urban-rural interface. Journal of Insect Conservation 18 : 815-826.

Statistica ver. 6.0 (2001) StatSoft Poland. Kraków.

Samnegård U., Persson A. S., Smith H. G. (201 1) Gardens benefit bees and enhance pollination in intensively managed farmland. Biological Conservation 144: 26022606 .

Suzuki K., Dohzono I., Hiei K., Fukuda Y. (2003) Pollination effectiveness of three bumblebee species on flowers of Hosta sieboldiana (Liliaceae) and its relation to floral structure and pollinator sizes. Plant Species Biology 17: 139-146. DOl: 10.1046/j.1442-1984.2002.00076.x

Takahashi H., Goto Y., Kanematsu S., Niwa S., Mori K., Nozaki K. (1 994) Pollination biology of Hosta sieboldiana (Lodd.) Engler and H. sieboldii (Paxton) J. Ingram (Liliaceae). Plant Species Biology 9: 23-30.

van Doorn W. G. (1997) Effects of pollination on floral attraction and longevity. Journal of Experimental Botany 48: 1615-1622. 
Waser N. M., Chittka L., Price M. V., Williams N. M., Wróblewska A., Stawiarz E. (2012) Flowering abundance Ollerton J. (1996) Generalization in pollination systems, and pollen productivity of Ligularia clivorum Maxim. and and why it matters. Ecology 77: 1043-1060. DOl: Ligularia przewalskii Maxim. Acta Scientiarum Polonorum. $10.2307 / 2265575$

Hortorum Cultus 11 (3): 57-67.

Willmer P. G., Stone G. N. (2004) Behavioral, ecological, and physiological determinants of the activity patterns of bees. Advances in the Study of Behavior 34: 347-466. 